Notre Dame Law School

NDLScholarship

Journal Articles

Publications

1981

\title{
The Basic Principles of Natural Law: A Reply to Ralph McInerny
}

John M. Finnis

Notre Dame Law School, john.m.finnis.1@nd.edu

Germain Grisez

Follow this and additional works at: https://scholarship.law.nd.edu/law_faculty_scholarship

Part of the Legal History Commons, and the Natural Law Commons

\section{Recommended Citation}

John M. Finnis \& Germain Grisez, The Basic Principles of Natural Law: A Reply to Ralph McInerny, 26 Am. J. Juris. 21 (1981). Available at: https://scholarship.law.nd.edu/law_faculty_scholarship/848 


\title{
THE BASIC PRINCIPLES OF NATURAL LAW: A REPLY TO RALPH MCINERNY
}

\author{
John Finnis and Germain Grisez
}

In the preceding volume of this journal, Prof. McInerny criticized certain theoretical positions of Finnis and Grisez as well as their interpretation of St. Thomas. In the present article Finnis and Grisez reply that McInerny's criticisms lack cogency, because he has misunderstood their theories, judged their exegesis by his own different interpretation assumed gratuitously to be correct, and mixed philosophical and historical criticism in a way which helps to clarify neither the problems of ethical theory nor those of Thomistic exegesis.

Ralph McInerny's "The Principles of Natural LaW"' ${ }^{1}$ is generous in its estimate of the significance of our work. But we think McInerny's criticism of Grisez's article, "The First Principle of Practical Reason,"2 and Finnis' treatise, Natural Law and Natural Rights, ${ }^{3}$ involves some serious misunderstandings of our views. We suspect that some of these misunderstandings are widely shared.

There is a methodological problem which makes a commentary on McInerny's article difficult. Grisez's article is a commentary on Summa theologiae, I-II, Question 94, Article 2, not a general treatment of Thomas' ethics, much less a summary of Grisez's own ethics. Finnis' treatise, by contrast, states and defends his own ethical theory. It points to texts of Thomas where "they can both illuminate and be illuminated by the theory presented in [the] book"; ${ }^{4}$ but it is not a commentary, and prescinds from the question whether it is ad mentem Divi Thomae. McInerny's article seems to take insufficient account of the restrictions of scope and purpose of the two works he has chosen to discuss.

McInerny says that his misgivings about "the Grisez interpretation [of the teaching of St. Thomas]" can mostly be grouped under three

1. 25 American Journal of Jurisprudence, pp. 1-15; hereinafter cited as McI.

2. "The First Principle of Practical Reason: A Commentary on the Summa theologiae, 1-2, Question 94, Article 2," 10 Natural Law Forum, pp. 168-201, hereinafter cited as FPPR. McInerny's references are to an abridged version in Anthony Kenny, ed., Aquinas: A Collection of Critical Essays (London: 1970), pp. 340-382. But the abridgement is not, as McInerny assumes (McI, p.1), a "reprint" of the original article. NLNR.

3. (New York and Oxford: Oxford University Press, 1980), hereinafter cited as

4. NLNR, p. v. 
headings. 5 So our reply also is under three headings. Under each we take space for only a few main points.

\section{I. "EXCESSIVE DISTINCTION BETWEEN FACT AND VALUE"6}

At one point McInerny suggests that we share "a view of practical reason that regards knowledge of the world to be irrelevant to it."7

All the references McInerny offers in respect to Finnis to support this suggestion are to pages in chapter II.4 of his book. These pages are devoted to a necessary polemic against modern critics who claim that Thomas makes the logical error of trying to deduce normative propositions from theoretical propositions ("ought" from "is") and who therefore dismiss him out of hand. A Thomist must read these pages with care, particularly their statements of what Thomas' theory is not. To find Finnis' positive account of Thomas' theory of the relation of fact to value, the Thomist should look a bit further on in the book. ${ }^{8}$ There Finnis explains:

Aquinas followed Aristotle's theory of the "induction" of indemonstrable first principles by insight working on observation, memory, and experience, but extended the account to a parallel "induction" of indemonstrable first principles of practical reason (i.e., of natural law) by insight working on felt inclinations and a knowledge of possibilities: S.T., I-II, q. 94, a.2. . .

Having explained that for Thomas those first practical principles are of the form " $\mathrm{X}$ is a good to be pursued . . .," Finnis gives his formal account of why such principles are principles of natural law:

. . . thirdly, the basic forms of good are opportunities of being; the more fully a man participates in them the more he is what he can be. And for this state of being fully what one can be, Aristotle appropriated the word physis, which was translated into Latin as natura ... So Aquinas will say that these requirements are requirements not only of reason, and of goodness, but also (by entailment) of (human) nature . . .10

Nor does Finnis himself think "knowledge of the world to be irrelevant" to practical reason, nor even to practical reason's grasp of its

5. $M c I$, p. 7 .

6. $M c I$, p. 7 .

7. $M c I$, p. 11 . 60 .

8. See especially $N L N R$, pp. $78-79$, which should be read with p. 45 , text at $n$.

9. NLNR, p. 77.

10. NLNR, p. 103, concluding with a reference back to pp. 35-36, where relevant texts of Thomas are quoted and analyzed. 
basic principles. Explaining what he means by "values cannot be derived from facts," he says: ". . . my contention is that, while awareness of certain 'factual' possibilities is a necessary condition for the reasonable judgment that truth is a value, still that judgment itself is derived from no other judgment whatsoever."1!

McInerny makes two points in connection with the fact-value distinction with respect to Grisez.

First, he quotes Grisez's use of the objection "that it is impossible to derive normative judgments from metaphysical speculations." 12 McInerny thinks this "suggests that there is something illicit in the passage from such sentences as

to

Wheaties are good for you

You ought to eat Wheaties."13

Later, McInerny says ${ }^{14}$ both of us consider it fallacious to pass from Knowledge is good for man

to

Men ought to pursue knowledge.

"Grisez and Finnis," McInerny says, "often speak of the first proposition as a metaphysical truth having nothing to do with practical judgments." 15 For this claim about what we "often speak of" no citation is given. None can be given, for we nowhere say any such thing.

One of the principles of practical thinking is that knowledge is a good to be pursued; this principle entails that knowledge ought to be pursued. But in the practical principle that knowledge is a good to be pursued, "good" is understood practically in the light of the first practical principle: Good is to be done and pursued. If "Knowledge is a good for man" were understood theoretically, simply as a truth of metaphysical anthropology, then it would have no more normative implication than "Knowledge is good for angels" has practical implication for us.

Nothing in our accounts of practical reason in general or of ethics in particular belittles or excludes as irrelevant to ethics a nonpositivist, teleological understanding of nature and of human persons insofar as

11. NLNR, p. 73 (emphasis added). Finnis repeatedly discusses the relevance of knowledge of the world: pp. 17-19, 65-66, 71, and 77 (last note).

12. $M c I$, p. 7, citing FPPR, p. 196.

13. $M C I$, p. 8.

14. $M c I$, p. 12.

15. $M c I$, p. 12 . 
they are part of nature. ${ }^{16}$ But if McInerny wishes to justify a conclusion such as

Joe ought to go on a diet

he had better not be content ${ }^{17}$ with premises such as

and

Joe weighs two hundred and fifty pounds

It is not healthy to be overweight.

One must assume a more basic practical premise

Health is a good to be pursued and protected

which itself is a specification of the very first principle of practical reason. This very first principle is not the truth of metaphysics or psychology, "Good is that which all men seek," as McInerny seems to think, ${ }^{18}$ but "Good is to be done and pursued and evil is to be avoided," as Thomas unequivocally says when he treats this matter in the famous passage on which Grisez commented.

Similarly, only with the practical principle, "Health is a good to be pursued and protected," and additional factual premises can one validly pass from "Wheaties are good for you" to "You ought to eat Wheaties." We have never said that one cannot pass from metaphysical and/or factual truths together with principles of practical reasoning to normative conclusions. Our point rather was that there can be no valid deduction of a normative conclusion without a normative principle, and thus that first practical principles cannot be derived from metaphysical speculations. ${ }^{19}$

The second point McInerny makes about Grisez with respect to fact and value is this:

Grisez says that in theoretical thinking the world calls the turn, in practical thinking the mind calls the turn. Often he suggests that

16. See FPPR, pp. 177 and 194.

17. As he seems to be: $M c l$, p. 12 .

18. $\mathrm{McI}$, p. 12.

19. See FPPR, pp. 193-196; NLNR, pp. 33-34. McI, p. 12, accuses us of "overfastidiousness" in our concern not to derive ought from is, and he suggests that "one man's fallacy may be another's common sense." We think that bad arguments have bad consequences; the lack of fastidiousness in much current ethics and moral theology is exacting a terrible price. Also important, careful exercise of reason according to the highest standards is to be valued for its own sake; lack of fastidiousness shows a remiss love of the basic human good of truth. As for common sense, we consider its inarticulateness about basic principles perfectly acceptable for the plain man. The philosopher, however, has the duty to try to explicate the assumptions of common sense. In the present instance, one fails philosophically if one evades the underivability of first practical principles (which Thomas says are per se nota-and what can this mean to McInerny?-) by falling back on (formally invalid) common sense reasoning, which always is enthemymatic. 
practical reason turns upon a malleable world which it can remake pretty much at will. ${ }^{20}$

Again, no citation is given. Grisez nowhere says or "suggests" any such absurdity as that practical reason turns upon a malleable world which it can remake pretty much at will. In saying that "the mind calls the turn" in practical knowledge, ${ }^{21}$ Grisez is making the same point as Thomas makes in the Prologue to his commentary on Aristotle's Ethics: that in contrast with the order of nature which reason finds and does not make, there are orders which reason itself makes-in the case of morally practical knowledge, in the acts of the will, and what is consequent upon them.

Grisez has taken pains elsewhere to show that there also necessarily is an order which reason does not make but only considers, an order of nature (including human nature), which is far from being "a malleable world which it [reason] can remake pretty much at will." 22 In the context of this exposition, Grisez sets out a thoroughly objectivist theory of value as fulfillment of possibility, in each order of reality, and emphasizes: "What the something is and to what order of entities it belongs must be taken for granted in distinguishing between the extent to which it already is, and the extent to which it is still short of its full possibility" 23 (and thus wanting in goodness). Thus for Grisez even in the moral world, where the mind calls the turn (reason makes, not finds, order), the subjectivism suggested by McInerny's unfortunate phrase, "can remake pretty much at will," is altogether excluded.

\section{BASIC VALUES AS PREMORAL}

In discussing the premoral character of the principles of natural law, McInerny seems to conclude that he agrees with what he thinks we perhaps also want to say on this question. ${ }^{24}$ But McInerny's view

20. $M c I$, p. 9 .

21. FPPR, p. 176. McInerny possibly is misled by his reliance on the Kenny abridgement, which so reduces Grisez's exposition of this point as to leave "the mind calls the turn" standing as an enigmatic, provocative slogan.

22. On the four orders distinguished by Thomas in the Prologue to his commentary on Aristotle's Ethics, and on the irreducibility of nature, see Germain Grisez, Beyond the New Theism: A Philosophy of Religion (Notre Dame and London: University of Notre Dame Press, 1975), pp. 230-240, 353-356, and the treatment of metaphysical relativism, pp. 205-225; see also Finnis, NLNR, pp. 136-139, 380, 389-391.

23. Grisez, Beyond the New Theism, p. 291.

24. $M c I$, p. 14. We do not here undertake to criticize Mclnerny's conception: end : means :: first principles of natural law: moral precepts deduced from the most common principles. But we do not concede the implicit theory, which seems to us to distort and greatly oversimplify the structure of moral reality and moral reasoning. 
of this matter presupposes his assumption that in the absolutely first principle, "Bonum est faciendum et prosequendum . . .," the word "bonum" refers to the ultimate end. ${ }^{25}$

Whether considered in itself or as an interpretation of Thomas, this presupposition seems to us quite untenable. Speaking of this absolutely first precept, McInerny comments:

The addressee is the human agent and the directive is: The perfection, the completion, the good in the sense of the ultimate end, is to be pursued and whatever is incompatible with that end is to be avoided.

Any other directive, any other precept which is a natural law precept, will be in effect a particularization of this one. That is, we shall expect that there will be a multiplicity of apprehensions each expressive of some constitutive of man's end or good. ${ }^{28}$

But note, first of all, that in Thomas' formula "Good is to be done and pursued," whereas in offering his interpretation, McInerny drops "to be done" and focuses on "to be pursued." This suppression of faciendum certainly facilitates the interpretation of bonum as ultimus finis. For either the last end is not done (though it may include doing), or, if the last end is done, it is done only when one rests in it and is no longer guiding action by reason toward it.

Second, it is by no means clear or even likely that Thomas considers all the goods to which man is naturally inclined (omnia illa ad quae homo habet naturalem inclinationem) to be constitutive of man's ultimate end. Indeed, what Aquinas does say about the ultimate end ${ }^{27}$ seems quite unlike McInerny's view that basic human goods are "con-

McInerny is mistaken, too, in thinking that Finnis considers first principles to be "not yet moral because they are too general" ( $M c I$, p. 13). Moreover, in treating Thomas" effort to elaborate moral precepts from the first practical principles, Finnis refers (NLNR, pp. 30, 101, 128) to many passages other than the single text (S.t., I-II, q. 100 , a.1) McInerny cites (McI, p. 13). So far as we understand it, we do not accept McInerny's interpretation of S.t., I-II, q. 100, a. 1; his translation of the passage he excerpts from the body of that article omits the word "immediately" (statim) which provides a pointer to the structure of Thomas' reply.

25. $M c I$, pp. 3-5. On p. 13, McInerny says: "What Finnis wants to distinguish from what he calls moral or ethical are those precepts which direct us to pursue our ultimate end or the constituents of it." But what Finnis wants to distinguish from moral precepts are the precepts articulated in S.t., I-II, q. 94, a. 2; and Finnis denies that these precepts are understood by Thomas (or should be understood by anyone) as directing us to our ultimate end. If Finnis thought that the first principles of practical reason direct us as McInerny thinks they do, then Finnis would have considered them to be moral precepts.

26. $M c I$, p. 4 .

27. S.t., I-II, qq. 1-5, especially, q. 3, a. 8. 
stitutive of" man's end. This view seems closer to Vatican $\mathrm{II}^{28}$ and to some things Grisez has said ${ }^{28}$ about the end of man than to the doctrine of Thomas.

Thirdly, Thomas holds that the absolutely first principle of practical reasoning is to its domain as the principle of noncontradiction is to the domain of thinking in general. ${ }^{30}$ If this is so, the first principle must govern the practical reasoning of people who do evil. The Don Juan considers fornication a good to be pursued. This consideration is not simply irrational and it is action-guiding; thus, Don Juan's immoral reasoning is governed by the first principle of practical reason. But he is acting against, not towards, the ultimate end of man.

McInerny supposes that what Finnis means by saying that basic principles of natural law are premoral is different from what Grisez means, in that Grisez "seems more concerned to have principles that will govern the practical activity of all men, good or bad, and which thus must split the difference between moral and immoral." 31 But the fact is that-setting aside the last phrase, which neither of us would accept-Finnis is concerned to make the same point as Grisez, and both of us consider this to be the position of Thomas. ${ }^{32}$ The basic principles of practical reasoning do underlie and make possible the reasoning of good people and bad people alike. The price for denying this is to say that the immoral are sheerly irrational, and thus free of moral responsibility.

However, neither of us has said that the immoral person responds to all the principles of practical reasoning and pursues goods consistently with all of them. The difference between moral good and moral evil arises just at this point. Practical principles do not "split the difference between moral and immoral"; rather, the less than upright conscience shapes action by some practical principles while ignoring others which also are relevant.

This important part of ethical theory (the problem of the first principle of morality) was not treated in the article of Grisez on which McInerny comments, for the simple reason that Thomas does not reach this problem in the passage on which Grisez was commenting. ${ }^{33}$

28. Gaudium et spes, sects. 38-39. Cf., e.g., Finnis, "Catholic Faith and World Order . . .," 64 The Clergy Review 309 (1979) at pp. 310, 317-318.

29. In "Man, the Natural End of," 9 New Catholic Encyclopedia (1967), pp. 137-138.

30. S.t., I-II, q. 94, a. 2; cf. FPPR, pp. 170, 175-179.

31. $M c l$, p. 10 .

32. See NLNR, pp. 30,51 , with references to Thomas.

33. Finnis has argued that Thomas' account of the difference between moral thinking and merely prudential reasoning (in the modern sense of "prudential") is "at 
When McInerny extended his critique to this problem, he ought to have attended to Grisez's treatment, in other works, of the first principle of morality. ${ }^{34}$

Since McInerny does not come to grips with our treatments of this problem, we say no more about them here. However, we do wish to stress that we would not call the basic human goods "premoral" in the same sense as do many contemporary moral thinkers and theologians who have adopted proportionalism. ${ }^{35}$ Proportionalists think of the basic human goods as kinds of desirable states of affairs, measurable and commensurable, which are more or less instantiated in and by means of human acts. We think of the basic human goods as aspects of the full-being of human persons, aspects essentially immeasurable and incommensurable. For the proportionalist, the right choice is one which realizes as much premoral good and as little premoral evil as possible. For us, the right choice is one which is in accord with open-hearted love of all the basic human goods. Thus, for the proportionalist the goods are premoral in the sense that one might rightly choose to destroy, damage, or impede them. For us, the goods are premoral only in the sense that both morally good and morally bad choices are directed (although in different ways) toward one or more of them (or, at least, toward some partial aspects or appearances of one or more of them).

\section{DENIAL OF OBJECTIVE HIERARCHY AMONG THE BASIC GOODS}

We have agrued ${ }^{3 B}$ that there is no objective hierarchy (i.e., none which would imply commensurability of value) among the basic forms of human good. McInerny says: "Finnis at any rate is aware that this tenet separates him from the text of Aquinas." 37 In fact,

best, highly elliptical, scattered, and difficult to grasp, and at worst, seriously underdeveloped; and that these deficiencies occasioned the unsatisfactory responses of those who professed to follow him in the later history of philosophical theology" (NLNR, p. 46). Finnis therefore gives his own account of the specific difference of the moral, and of moral virtue (NLNR, ch. V).

34. E.g., Germain Grisez and Joseph M. Boyle, Jr., Life and Death with Liberty and Justice: A Contribution to the Euthanasia Debate (Notre Dame and London: University of Notre Dame Press, 1979), pp. 361-368; Germain Grisez and Russell Shaw, Beyond the New Morality: The Responsibilities of Freedom, 2nd ed. (Notre Dame and London: University of Notre Dame Press, 1980), pp. 80-101.

35. For our criticisms of proportionalism, see NLNR, pp. 112-118; Germain Grisez, "Against Consequentialism," 23 American Journal of Jurisprudence (1978), pp. 21-72.

36. NLNR, pp. 92-95; Beyond the New Morality, pp. 74-78.

37. $M c I$, p. 10. Grisez does not discuss the question of hierarchy of values in the article on which McInerny is commenting; he explicitly prescinds (FPPR, pp. 180181) from the problems of this part of the article of Thomas on which he comments. 
Finnis does not think that this tenet does separate him from the text of Thomas; Finnis says that Thomas' rationale for the "order" of the precepts of natural law "all too easily is interpreted as a ranking."38 We deny what McInerny affirms, namely, that our position "collide[s] in important ways with Thomas' understanding." 39

It is arbitrary to suppose that all order is hierarchy, and still more arbitrary to assume that the corresponding order of the precepts of natural law and of natural inclination identified by Thomas in Summa theologiae, I-II, q. 94, a. 2, is a hierarchy of value. The principle of the order identified there by Thomas is simply: what man "has in common with all substances," "has in common with all animals," and has "peculiar to himself." Why should this metaphysical principle of ordering be interpreted as a ranking of values? No doubt Aristotle has an argument that man's highest good is the good most proper to him. ${ }^{40}$ But where does Thomas make this argument his own? ${ }^{41}$ Would it not be disastrous for a Christian theologian, who thinks that man's supreme good is communion with God, to adopt Aristotle's line of argument, when communion with the divine persons is not proper to man, but is naturally proper only to the divine persons themselves, and is shared by their supernatural gift not only with men but also with angels?

We do not find in Thomas' text McInerny's theory that "if we enumerate [man's] inclinations and notice their hierarchy we will be able to glimpse the natural law precepts which take them into account." 12 What Thomas does say is that "all those things to which man has a natural inclination, reason naturally grasps as goods and, in consequence, as things-to-be-pursued by work, and their opposites as evils and things-to-be-avoided."43 We do not find in Thomas what McInerny thinks he finds: that "goods which are not peculiar to men come to be constituents of the human good insofar as they come under the sway of the distinctive mark of human agent, reason." 44 Nor do

Nevertheless, McInerny criticizes what he takes to be Grisez's position without providing any reference to the places where Grisez states and defends it.

38. NLNR, p. 94.

39. $M c I$, p.11.

40. Eth. Nic. X, 7 (1178a4-5); cf. I, 7 (1097b24-1098a7).

41. The argument in S.t., I-II, qq. $2-3$, is considerably more complex, precisely because Thomas does hold that communion with God is the ultimate fulfillment of man.

42. $M c I$, p. 4.

43. S.t., I-II, q. 94, a. 2 , c.; the reply ad 2 is cryptic and must be interpreted in accord with the body of this article.

44. $M C I$, p. 4. McInerny adds: "Sex is a human good not just as such, but as engaged in consciously and purposively and responsibly." By so saying he seems to 
we think Thomas' text supports McInerny's further interpretation: "Precepts of natural law are rational directives aiming at the good for man. The human good, man's ultimate end, is complex but the unifying thread is the distinctive mark of the human, i.e., reason." 45 The first sentence undoubtedly expresses Thomas' position, but the second does not follow from the first, and will seem thomistic only to those who read into Thomas a degree and kind of Aristotelianism we do not find in him.

Thomas is clear enough that the primary precepts of the natural law identify the goods (in the plural) for man, and that among these goods is the good corresponding to the natural inclination to act according to reason. ${ }^{48}$ But this inclination is only one among many, and all the inclinations are for goods naturally understandable by reason. Where does Thomas formulate the primary precepts of natural law in McInerny's mode: "Rationally pursue self-preservation," "Rationally pursue the good of sex, reproduction, offspring," and so on? What Thomas says more naturally suggests formulations in the mode: "Life is a good to be pursued and protected" and so on.

Even if Thomas' text supported an Aristotelian hierarchy of human goods, as McInerny believes, we would reject such a hierarchy. Our reason for doing so would be not only the noncommensurability of the basic goods, which blocks proportionalist rationalizations (which McInerny takes to be our sole concern), but also the transcendence of the good of the first principle of practical reason. As Grisez explains in a section of his article deleted in the Kenny abridgement:

Only by virtue of this transcendence is it possible that the end proposed by Christian faith, heavenly beatitude, which is supernatural to man, should become an objective of genuine human action-that is, of action under the guidance of practical reason. If the first principle of practical reason restricted human good to the goods proportionate to nature, then a supernatural end for human action would be excluded. The relation of man to such an end could be established only by a leap into the transrational where human action would be impossible and where faith would replace natural law rather than supplement it. ${ }^{47}$

imply that the sexual capacity of human persons is per se infrahuman-an assumption which entails an indefensible dualism and which also is inconsistent with the use of S.t., I-II, q. 94, a. 2, which Paul VI makes in Humanae vitae, sect. 10.

45. $\mathrm{Mcl}, \mathrm{p} .5$.

46. S.t., I-II, q. 94 , a. 3 , c.

47. FPPR, p. 200. That human nature grounds without limiting the possibilities open to humankind through freedom is an important truth of anthropology, unknown to Aristotle, articulated in the light of Christian faith in the supernatural vocation of humankind to fulfillment in Christ, and now universally accepted (although distorted) by contemporary, "postchristian" humanism of all sorts. 
As Grisez argued in another article, contemporaneous with the one on which McInerny comments, Thomas' theory of the natural end of man remains incoherent just to the extent that he was more Aristotelian than the reality of human nature, open to divine life, allows. ${ }^{48}$

IV.

Because they rest on misunderstandings, McInerny's critical remarks on our work seem to us to lack cogency. These misunderstandings were compounded, we think, by McInerny's decision to criticize simultaneously our exegeses of Thomas' texts and our own independent theorizing.

We find nothing in McInerny's article which requires us to concede error in our reading of Thomas. To assume a different, "AristotelianThomistic," reading of Thomas and to point out that we do not share that reading could be the point of departure for criticism of our reading. But until the alternative reading is established by arguments, its mere assertion against ours is question-begging.

McInerny's criticisms of our independent theorizing are all based upon the presupposed authority of what we have called AristotelianThomism. Admirable as this philosophy is in some respects, we do not consider it as perfect as McInerny seems to think it is. Moreover, the fact that we sometimes purposely differ with Thomas himself clearly does not entail that we misinterpret him, unless one assumes that all of Thomas' positions are self-evident to those who correctly understand them.

McInerny ends his article by suggesting that a major task before us "is to draw out the relation between ultimate end and the Treatise on Law." Grisez's work in ethics began precisely as an attempt to carry out this task. He became convinced that Thomas' account of the ultimate end is inconsistent with his account of natural law. This conviction led him to develop his own ethical theory, which is heavily indebted to Thomas but which is autonomously grounded. We think that all who are interested in natural law would do well to shoulder the responsibility of independent philosophical work, as we and many others have done, rather than to continue to be content with neoscholastic commingling of historical interpretation and philosophical construction.

48. "Man, the Natural End of," pp. 134-135. 